\title{
IN VITRO EFFICACY OF AQUEOUS NEEM EXTRACT AND DELTAMETHRIN AGAINST SARCOPTES SCABIEI VAR. CUNICULI AND IN VIVO USING EXPERIMENTALLY INFESTED RABBITS
}

\author{
ALI M. ALI*; SHAKER A. SEDDIEK ${ }^{* *}$; MAI O. NADA* and SAMEH A. EL-ALFY*** \\ *Biochemistry, Toxicology and Nutritional Deficiency Diseases Department \\ **Avian Diseases Department \\ ***:Parasitology Department \\ Animal Health Research Institute, Benha-Branch. Agriculture Research Center (ARC).
}

Received at: 11/3/2015

Accepted: 15/4/2015
Sarcoptes scabiei var. cuniculi is an important ectoparasites in rabbits. The acaricidal activity of aqueous extract of neem (AEN) and deltamethrin (DMT) were evaluated. Rabbits were classified into four equal groups. The first group represented the negative control group. Each rabbit of the other groups was experimentally infested with 50 mites. One month post-infestation, the second group considered as the positive control group. The third group was treated topically with DMT $0.005 \%$ solution. Finally, the fourth group was treated topically with $25 \%$ AEN. In vitro, AEN (40\%) was highly efficacious against larvae of S. scabiei var. cuniculi as $100 \%$ mortality was reached $24 \mathrm{~h}$ post-treatment (PT). In vivo, Twentyeight days PT, the reduction percentages of mites infesting rabbits were 93.07 and $92.81 \%$ for DMT and AEN, respectively, while complete mite reduction was reached 42 days PT with AEN. All biochemical analyses \& growth performance parameters returned to normal levels in AEN \& DMT treated rabbits at $28 \& 42$ days PT. Our study indicated that AEN had in vitro and in rabbits acaricidal efficiency similar to that of DMT and improved the performance of rabbits without inducing adverse effects on treated rabbits.

Key words: In vitro, Aoueous neem extract, Deltamethrin against, Sarcoptes scabiei var. cuniculi.

\section{INTRODUCTION}

Sarcoptic mange belongs to the family sarcoptidae and it's a highly contagious and burrowing parasite (Walton and Currie, 2007). Sarcoptes scabiei is an important rabbit ectoparasite because of the possibility of zoonotic infection (Harrenstien et al., 1995) and considerable losses in weight, productivity, wool, and fiber quality.

In Egypt, mange (Sarcoptes and Psorptic) in rabbits is considered to be second to coccidiosis importance, with high losses. Sarcoptes scabiei var. cuniculi causes mange infestation in rabbits, affecting their nose, feet, and areas around the genitalia, resulting in hypertensive reaction, body weight loss, and death (Saha and Mukherjee 1998). S. scabiei can be difficult to eliminate in rabbits compared to other domestic animals (Aiello et al., 1998).
There is extensive evidence of the activity of the pyrethroids, such as deltamethrin, pyrethin, cypermethrin and tetramethrin, when they are used as topical pesticides. Deltamethrin is a pyrethroid with strong insecticidal activity and photo-stability and low mammalian toxicity and acts on the insect's central nervous system to give a rapid knockdown. It brings acaricidal and repellent effects against ticks, mites and biting insects, thus providing protection from the transmission of diseases (Mehlhorn et al., 2011).

In general, many of the chemical acaracides have limitations such as resistance (Currie et al., 2004) and toxicity (O'Brien 1999), environmental contamination, and persistence (Halley et al., 1993; O'Brien 1999). Such side effects of chemical acaricides have prompted a search for new alternatives (Khater et al., 2013a, b). 
Medicinal plants have been used as a source of remedies since ancient times. The ancient Egyptians were familiar with many medicinal herbs and were aware of their usefulness in the treatment of various diseases. Egypt possesses an enormous diversity of plant resources that is used for herbal remedies for humans and animals (Mohamed et al., 2010; Seddiek et al., 2011; Khater et al., 2013a, b).

Botanicals have been in nature for millions of years without any adversative effects on the ecosystem. Botanical extracts kill and repel pests (Khater et al., 2009), affect insect growth and development (Shalaby and Khater 2005; Khater and Shalaby 2008), and have anti-feedant and arrestant effects. As a consequence, botanical acaricides have become research hot spots because of their environmental safety and efficacy (Khater 2011, 2012, 2013).

Neem (Azadirachta indica A. Juss) has multipurpose medicinal properties, including antibacterial (ElMahmood et al., 2010), antifungal, immunestimulant, antipyretic (Biswas et al., 2002), and acaricidal activities (Mulla and Su 1999). Neem was found to have biocidal activity against nearly 200 medical and veterinary arthropods, without any adverse effects toward most non-target organisms. As an acaricide, neem oil is effective against S. scabiei (Du et al., 2007), ticks (Abdel-Shafy and Zayed 2002), and poultry red mites (Lundh et al., 2005).

The aims of this work were to evaluate the acaricidal efficacy (in vitro and in vivo) of the crude aqueous extract of neem (AEN) and deltamethrin (DMN) against S. scabiei var. cuniculi and their effects on some biochemical parameters and growth performance of rabbits experimentally infested with sarcoptic mite.

\section{MATERIALS and METHODS}

\section{Collection of mites}

S. scabiei var. cuniculi larvae were collected from naturally infested rabbits in Qalyubia governorate, Egypt. The scabs containing mites were placed in Petri dishes, which were incubated at $35{ }^{\circ} \mathrm{C}$ for 30 min. Under a stereomicroscope, the motile larvae were used in the experiments. Larvae have six legs, which makes them easily distinguishable from nymphs and adults, which have eight legs. Mites were identified according to Soulsby (1982).

\section{Chemical acaricide}

Deltamethrin (Butox® 50 EC) was purchased from the Intervet Company, Cairo, Egypt. Each milliliter of (Butox® $50 \mathrm{EC}$ ) contains $50 \mathrm{mg}$ deltamethrin (DMT). We prepared DMT topical solution by adding $1 \mathrm{ml}$ of
Butox® 50 EC to 1 liter distilled water (DW) to obtain DMT topical solution with concentration of $0.005 \%$ (50 mg DMT/Liter DW), according to the producer.

\section{Plant material and extraction}

Fresh leaves of Neem, Azadirachta indica A. Juss (A. indica), were collected from Giza, Egypt, in May 2014. The crude aqueous leaf extract of neem (AEN) was prepared according to Haussain (2002), with some modifications. Leaves of A. indica were dried indoors and then ground and weighed (5, 10, 20, 25, 30 , and $40 \mathrm{~g}$ ). Ground leaves were soaked in $100 \mathrm{ml}$ distilled water for 24 hours (h) and then homogenized in an electric blender. The homogenate was altered through a sterilized triple-folded piece of gauze. The filtrates $(5,10,20,30$, and $40 \%)$ were used for in vitro bioassays while; the filtrate $25 \%$ was used for in vivo experiment.

\section{Acaricidal activity in vitro}

Regarding the concentration response bioassay, studying the acaricidal property was done according to Khater and Ramadan (2007). Five doses of AEN with four replications for each concentration were used in vitro. Twenty larvae per replicate were placed in a clean dry Petri dish with a filter paper, disc of Whatman no. 1 filter paper with surface areas measuring $62.63 \mathrm{~cm}^{2}$, and impregnated uniformly with the used concentration of AEN on the bottom. The bioassay trails were carried out with increasing concentrations of $\operatorname{AEN}(5,10,20,30$, and $40 \%)$ and contact time (24, 48, and $72 \mathrm{~h}$ ). Two other groups were used: the first one (control) was treated with distilled water and the second group was treated with DMT $0.005 \%$. Bioassays were done at $27 \pm 2{ }^{\circ} \mathrm{C}$ and $75 \pm 5 \%$ relative humidity $(\mathrm{RH})$. Immobility of the larval mites, even when stimulated with a needle, the lack of a response, and persistent immobility were considered indicative of death (Khater and Ramadan 2007; Khater et al., 2013b).

\section{Experimental animals}

Forty New Zealand male rabbits (mean weight, $757.23 \pm 5.46 \mathrm{~g}$ ) were purchased from the Faculty of Agriculture, Benha University, Egypt. All rabbits were healthy and fed on balanced rations and a clean source of water ad libitum. These rabbits had not been treated with any anti-acariasis drug. The sampling procedures adhered to institutional ethical and animal care guidelines, and all methods were conducted in accordance with the Guide for the Care and Use of Laboratory Animals, according to Nong et al. (2013).

\section{Experimental design and treatment strategy}

Forty rabbits were classified into four equal groups (ten rabbits each). The first group was designated as the healthy or negative control group (non-infested and non-treated). Each rabbit in the other groups was 
experimentally infested with 50 mites (Larvae). The infestation was carried out on the dorsal area (4X2 $\mathrm{cm}$ ) after scratching the fur. One month postinfestaotion, the second group was not treated and taken into account as the positive control group. The third group was treated topically with deltamethrin (DMT) $0.005 \%$ solution, once every three days for three consecutive weeks. Finally, the fourth group was treated topically with $25 \%$ AEN (the concentration which showed lethal concentration 99 (LC99) value $48 \mathrm{~h}$ post-treatment, PT) every 3 days for three consecutive weeks, according to Haussain (2002).

\section{Clinical score value descriptions}

Index scoring of lesions was described weekly according Jensen et al. (2002) as follows: $0=$ no lesion; $1=$ mild lesion-small visible mange body lesion (diameter, 0-4 cm), no bloody skin injuries, good overall body condition, only occasional ebbing; $2=$ moderate lesion-medium-sized visible mange body lesion (diameter, 4-8 cm), no bloody skin injuries, good overall body condition, more sequent rubbing; $3=$ severe lesion-severe body mange skin lesion, bloody skin injuries due to rubbing, reduced overall body condition; 4=chronic lesion-thick asbestos-like scab in the body, bloody skin injuries due to rubbing, marked reduced overall body condition. Skin scrapings were taken from the part of the lesions bordering healthy tissue by scraping the infested areas. The number of live mites (larvae, nymphs, and adults) on each rabbit was counted on the $14^{\text {th }}, 28^{\text {th }}$, and $42^{\text {th }}$ day PT.

\section{Biochemical analyses}

Blood samples were taken from the ear veins of five rabbits per group two times, 28 and 42 days PT, to separate the serum, which was stored at $-20{ }^{\circ} \mathrm{C}$ until used for estimating the activity of serum alanine aminotransferase (ALT) and aspartate aminotransferase (AST) (Varliy, 1974), cholesterol (Flegg, 1973), creatinine (Henry, 1974), total protein (Domas, 1975), albumin (Dogmas, 1971), and globulin.

\section{Rabbit performance}

The body weight and cumulative body weight gain of rabbits were recoded 14,28 , and 42 days PT.

\section{Statistical analysis}

In bioassay tests, probit analysis was done on mortality data (Finney, 1971) using a computer program (Biostat, 2009) to calculate the lethal concentration (LC) and lethal time (LT) values. The biological data were subjected to analysis of variance (ANOVA) with Duncan's multiple range test
(Duncan, 1955) using SPSS, a computer software (SPSS, 2009).

\section{RESULTS}

AEN (40\%) was highly efficacious against S. scabiei var. cuniculi larvae as $100 \%$ mortality was reached $24 \mathrm{~h}$ PT. On the other hand, all mites treated with AEN $(20 \%)$ and DMT $(0.005 \%)$ died $48 \mathrm{~h}$ PT (Table 1). The lethal values of AEN (LC50, LC90, LC95, and LC99) were 7.65, 14.97, 18.11, and 25.88 $\%$, respectively, $48 \mathrm{~h}$ PT (Table 2). Lesion scoring in DMT $(0.005 \%)$ and AEN $(25 \%)$ treated groups were significantly decreased $(\mathrm{P}<0.05)$, reaching 0.21 and 0.41 , respectively, when compared with that of positive control group (4.08), 42 days PT (Table 3 ).

Rabbits infested with S. scabiei var. cuniculi adult and not treated (positive control group) showed sarcoptic mange on the nose. The affected regions showed scales, alopecia, and scale formation. Rabbits showed pruritis and were intermittently scratching the area with front paws. Later, hemorrhagic crusts with Assures developed, even becoming eroded in places. Rabbits showed minor signs of recovery. In contrast, rabbits treated with AEN exhibited improvement of clinical signs during the experiment, no inflammation was observed, and showed absence of macroscopic lesions on the nose, and legs after 42 days PT. Similar results had been reported for the DMT-treated group.

Twenty-eight days PT, the reduction percentages of mites infesting rabbits were $93.07 \%$ and $92.81 \%$ for DMT and AEN, respectively. However, complete mite reduction was reached at 42 days PT (Table 4). Rabbits treated with AEN did not show signs of restlessness or irritation, respiratory signs, or inflammation on the eye and/or skin at the time of application or afterwards.

Regarding biochemical analyses at 42 days PT, the levels of AST and total cholesterol of rabbits infested with S. scabiei var. cuniculi and not treated (positive control group) were significantly increased $(\mathrm{P}<0.05)$ than those of rabbits of the negative control group and those treated with DMT $(0.005 \%)$ or AEN $(25 \%)$ (Table 5). On the other hand, the levels of total protein, albumin, and globulin of positive control group were significantly decreased $(\mathrm{P}<0.05)$ when compared with the corresponding values of other groups (Table 6). The body weight and cumulative body weight gain of rabbits treated with AEN were significantly increased $(\mathrm{P}<0.05)$ when compared with such values of positive control group \& those treated with DMT $(0.005 \%)$, on 28 and 42 days PT (Table 7). 
Table 1: In vitro mortality percentage of S. scabiei var. cuniculi larvae after treatment with different concentrations of aqueous extract of neem and the recommended dose of deltamethrin.

\begin{tabular}{|c|c|c|c|c|c|c|c|c|c|}
\hline \multirow{3}{*}{ Concentrations } & \multicolumn{9}{|c|}{ Time post-treatment (hours) } \\
\hline & \multicolumn{3}{|c|}{24} & \multicolumn{3}{|c|}{48} & \multicolumn{3}{|c|}{72} \\
\hline & $\mathrm{D}$ & $\mathrm{L}$ & $\mathrm{M} \%$ & $\mathrm{D}$ & $\mathrm{L}$ & M\% & $\mathrm{D}$ & $\mathrm{L}$ & $\mathrm{M} \%$ \\
\hline Control & 2 & 78 & 2.50 & 5 & 75 & 6.25 & 8 & 72 & 10.00 \\
\hline DMT $(0.005 \%)$ & 74 & 6 & 92.50 & 80 & 0 & 100.00 & 80 & 0 & 100.00 \\
\hline $\operatorname{AEN}(5 \%)$ & 13 & 67 & 16.25 & 13 & 67 & 16.25 & 25 & 55 & 31.25 \\
\hline AEN (10\%) & 33 & 47 & 41.25 & 33 & 47 & 41.25 & 62 & 18 & 77.50 \\
\hline AEN $(20 \%)$ & 55 & 25 & 68.75 & 80 & 0 & 100.00 & 80 & 0 & 100.00 \\
\hline AEN (30\%) & 67 & 13 & 83.75 & 80 & 0 & 100.00 & 80 & 0 & 100.00 \\
\hline AEN (40\%) & 80 & 0 & 100.00 & 80 & 0 & 100.00 & 80 & 0 & 100.00 \\
\hline
\end{tabular}

$\mathrm{D}=$ Dead larvae. $\mathrm{L}=$ Live larvae. $\mathrm{M} \%=$ Mortality percentage. $\mathrm{DMT}=$ Deltamethrin. $\mathrm{AEN}=$ Aqueous extract of neem.

Table 2: In vitro sensitivity of S. scabiei var. cuniculi larvae to aqueous extract of neem with determination of its effective lethal time against the mites. (Mean \pm SEM).

\begin{tabular}{cccc}
\hline & \multicolumn{2}{c}{ Time post-treatment (hours) } & \\
\cline { 2 - 4 } & 24 & 48 & 72 \\
\hline $\mathrm{LC}_{50}$ & $11.91 \pm 0.82$ & $7.65 \pm 0.24$ & $6.52 \pm 0.18$ \\
\hline $\mathrm{LC}_{90}$ & $32.80 \pm 1.04$ & $14.97 \pm 1.03$ & $12.78 \pm 1.06$ \\
\hline $\mathrm{LC}_{95}$ & $43.71 \pm 2.52$ & $18.11 \pm 1.16$ & $15.47 \pm 1.14$ \\
\hline $\mathrm{LC}_{99}$ & $74.89 \pm 2.74$ & $25.88 \pm 1.22$ & $22.14 \pm 1.17$ \\
\hline $\mathrm{Slope}^{1}$ & $2.97 \pm 0.12$ & $4.48 \pm 0.25$ & $4.47 \pm 0.02$ \\
\hline
\end{tabular}

$\mathrm{SEM}=$ stander error of mean. $\mathrm{LC}=$ lethal concentration. $\mathrm{LT}=$ lethal time.

${ }^{1}$ Slope of the regression lines.

$\mathrm{LT}_{50}$ values for $5 \%$ and $10 \%$ of aqueous extract of neem were $160.100 \pm 13.257$ and $33.973 \pm 2.451$, respectively.

Table 3: Index scoring of S. scabiei var. cuniculi adult infested rabbits after treatment with aqueous extract of neem and deltamethrin. (Mean \pm SEM).

\begin{tabular}{|c|c|c|c|c|c|c|}
\hline & \multicolumn{6}{|c|}{ Days post-treatment } \\
\hline & 7 & 14 & 21 & 28 & 35 & 42 \\
\hline -ve control & $0.00 \pm 0.00^{b}$ & $0.00 \pm 0.00^{c}$ & $0.00 \pm 0.00^{c}$ & $0.00 \pm 0.00^{\mathrm{c}}$ & $0.00 \pm 0.00^{b}$ & $0.00 \pm 0.00^{b}$ \\
\hline +ve control & $2.04 \pm 0.01^{\mathrm{a}}$ & $2.65 \pm 0.12^{\mathrm{a}}$ & $3.47 \pm 0.21^{\mathrm{a}}$ & $3.67 \pm 0.24^{\mathrm{a}}$ & $3.88 \pm 0.24^{\mathrm{a}}$ & $4.08 \pm 0.24^{\mathrm{a}}$ \\
\hline DMT & $1.65 \pm 0.02^{\mathrm{a}}$ & $1.65 \pm 0.03^{b}$ & $1.44 \pm 0.05^{b}$ & $1.24 \pm 0.07^{\mathrm{b}}$ & $0.41 \pm 0.24^{b}$ & $0.21 \pm 0.24^{b}$ \\
\hline $\mathrm{AEN}$ & $1.71 \pm 0.04^{\mathrm{a}}$ & $1.85 \pm 0.07^{b}$ & $1.65 \pm 0.06^{b}$ & $1.44 \pm 0.08^{b}$ & $0.62 \pm 0.24^{b}$ & $0.41 \pm 0.24^{b}$ \\
\hline
\end{tabular}

SEM=stander error of mean. -ve control: negative control (not infested \& not treated); +ve control: positive control (Infested \& not treated); DMT: infested and treated with deltamethrin locally $(0.005 \%)$; AEN $=$ infested and treated with aqueous extract of neem locally (25\%). ${ }^{\mathrm{a}-\mathrm{c}}$ Mean values within a column followed by different lowercase letters were significantly different $(\mathrm{P} \leq 0.05)$. Index scores according to Jensen et al. (2002). 
Table 4: Reduction percentage of live mite on the infested rabbits after treatment with aqueous extract of neem and deltamethrin.

\begin{tabular}{|c|c|c|c|c|c|c|}
\hline & \multicolumn{6}{|c|}{ Days post-treatment } \\
\hline & \multicolumn{2}{|l|}{14} & \multicolumn{2}{|l|}{28} & \multicolumn{2}{|l|}{42} \\
\hline & $\mathrm{M} \pm \mathrm{SEM}$ & $\mathrm{R} \%$ & $\mathrm{M} \pm \mathrm{SEM}$ & $\mathrm{R} \%$ & $\mathrm{M} \pm \mathrm{SEM}$ & $\mathrm{R} \%$ \\
\hline -ve control & $0.00 \pm 0.00^{c}$ & - & $0.00 \pm 0.00^{\mathrm{c}}$ & - & $0.00 \pm 0.00^{b}$ & - \\
\hline +ve control & $98.70 \pm 1.04^{\mathrm{a}}$ & 0.00 & $137.00 \pm 1.03^{\mathrm{a}}$ & 0.00 & $182.11 \pm 4.36^{\mathrm{a}}$ & 0.00 \\
\hline DMT & $35.35 \pm 2.32^{b}$ & 64.18 & $9.50 \pm 1.06^{b}$ & 93.07 & $0.00 \pm 1.03^{b}$ & 100.00 \\
\hline $\mathrm{AEN}$ & $39.55 \pm 2.24^{\mathrm{b}}$ & 59.93 & $9.85 \pm 1.02^{b}$ & 92.81 & $1.56 \pm 1.07^{b}$ & 99.14 \\
\hline
\end{tabular}

$\mathrm{M}=$ mean number of live mites (larvae, nymphs \& adults). SEM=stander error of mean. $\mathrm{R} \%=$ Reduction percentage. -ve control: negative control (not infested \& not treated); +ve control: positive control (Infested \& not treated); DMT: infested and treated with deltamethrin locally $(0.005 \%) ; \mathrm{AEN}=$ infested and treated with aqueous extract of neem locally $(25 \%)$.

${ }^{\mathrm{a}-\mathrm{c}}$ Mean values within a column followed by different lowercase letters were significantly different $(\mathrm{P} \leq 0.05)$.

Table 5: Some serum biochemical parameters in rabbits treated with crude aqueous extract of neem or deltamethrin. (Mean \pm SEM).

\begin{tabular}{|c|c|c|c|c|c|c|c|c|}
\hline & \multicolumn{2}{|c|}{ AST (U/L) } & \multicolumn{2}{|c|}{$\operatorname{ALT}(\mathbf{U} / \mathbf{L})$} & \multicolumn{2}{|c|}{ Creatinine (mg/dL) } & \multicolumn{2}{|c|}{ Total cholesterol $(\mathbf{m g} / \mathbf{d L})$} \\
\hline & 28 & 42 & 28 & 42 & 28 & 42 & 28 & 42 \\
\hline $\begin{array}{l}\text {-ve } \\
\text { control }\end{array}$ & $40.23 \pm 2.81^{\mathrm{b}}$ & $39.55 \pm 2.15^{\mathrm{b}}$ & $35.61 \pm 2.47^{\mathrm{a}}$ & $36.57 \pm 2.17^{\mathrm{a}}$ & $1.25 \pm 0.01^{\mathrm{a}}$ & $1.37 \pm 0.04^{\mathrm{a}}$ & $58.43 \pm 3.72^{\mathrm{b}}$ & $60.32 \pm 3.63^{b}$ \\
\hline $\begin{array}{l}+\mathrm{ve} \\
\text { control }\end{array}$ & $63.12 \pm 3.22^{\mathrm{a}}$ & $72.45 \pm 4.52^{\mathrm{a}}$ & $40.12 \pm 1.72^{\mathrm{a}}$ & $40.83 \pm 2.84^{\mathrm{a}}$ & $0.96 \pm 0.02^{\mathrm{a}}$ & $1.18 \pm 0.01^{\mathrm{a}}$ & $72.62 \pm 4.83^{\mathrm{a}}$ & $76.54 \pm 3.77^{\mathrm{a}}$ \\
\hline DMT & $41.28 \pm 1.72^{b}$ & $38.73 \pm 1.88^{b}$ & $38.48 \pm 2.64^{\mathrm{a}}$ & $38.96 \pm 1.46^{\mathrm{a}}$ & $1.15 \pm 0.01^{\mathrm{a}}$ & $1.31 \pm 0.06^{\mathrm{a}}$ & $59.46 \pm 3.44^{\mathrm{b}}$ & $61.45 \pm 4.14^{\mathrm{b}}$ \\
\hline AEN & $42.19 \pm 2.52^{\mathrm{b}}$ & $37.85 \pm 2.62^{\mathrm{b}}$ & $39.53 \pm 1.42^{\mathrm{a}}$ & $40.11 \pm 1.89^{\mathrm{a}}$ & $0.98 \pm 0.06^{\mathrm{a}}$ & $1.22 \pm 0.05^{\mathrm{a}}$ & $60.24 \pm 3.64^{b}$ & $58.78 \pm 3.43^{b}$ \\
\hline
\end{tabular}

AST: Aspartate aminotransferase; ALT: Alanine transaminase; SEM: stander error of mean; -ve control: negative control (not infested \& not treated); +ve control: positive control (Infested \& not treated); DMT: infested and treated with deltamethrin locally $(0.005 \%)$; AEN= infested and treated with aqueous extract of neem locally $(25 \%)$.

${ }^{\mathrm{a}-\mathrm{b}}$ Mean values within a column followed by different lowercase letters were significantly different $(\mathrm{P} \leq 0.05)$.

Table 6: Serum total protein, albumin, and globulin in rabbits treated with crude aqueous extract of neem or deltamethrin. (Mean \pm SEM).

\begin{tabular}{|c|c|c|c|c|c|c|}
\hline & \multicolumn{2}{|c|}{ Total protein $(\mathrm{g} / \mathrm{dL})$} & \multicolumn{2}{|c|}{ Albumin (g/dL) } & \multicolumn{2}{|c|}{ Globulin (g/dL) } \\
\hline & 28 & 42 & 28 & 42 & 28 & 42 \\
\hline -ve control & $5.82 \pm 0.08^{a}$ & $5.94 \pm 0.12^{\mathrm{a}}$ & $3.12 \pm 0.12^{\mathrm{a}}$ & $3.32 \pm 0.06^{\mathrm{a}}$ & $2.70 \pm 0.08^{a}$ & $2.62 \pm 0.11^{\mathrm{a}}$ \\
\hline +ve control & $4.46 \pm 0.14^{\mathrm{c}}$ & $4.16 \pm 0.25^{b}$ & $2.31 \pm 0.07^{\mathrm{c}}$ & $2.12 \pm 0.03^{b}$ & $2.15 \pm 0.17^{\mathrm{c}}$ & $2.04 \pm 0.08^{b}$ \\
\hline $\mathrm{DMT}$ & $5.24 \pm 0.26^{b}$ & $5.73 \pm 0.17^{\mathrm{a}}$ & $2.87 \pm 0.02^{b}$ & $3.43 \pm 0.02^{\mathrm{a}}$ & $2.37 \pm 0.13^{b}$ & $2.30 \pm 0.07^{\mathrm{a}}$ \\
\hline AEN & $5.55 \pm 0.31^{a}$ & $5.89 \pm 0.27^{\mathrm{a}}$ & $2.98 \pm 0.10^{\mathrm{a}}$ & $3.36 \pm 0.05^{\mathrm{a}}$ & $2.57 \pm 0.07^{\mathrm{a}}$ & $2.53 \pm 0.13^{a}$ \\
\hline
\end{tabular}

SEM: stander error of mean; -ve control: negative control (not infested \& not treated); +ve control: positive control (Infested \& not treated); DMT: infested and treated with deltamethrin locally $(0.005 \%)$; $\mathrm{AEN}=$ infested and treated with aqueous extract of neem locally $(25 \%)$. ${ }^{\mathrm{a}-\mathrm{c}}$ Mean values within a column followed by different lowercase letters were significantly different $(\mathrm{P} \leq 0.05)$. 
Table 7: Body weight and body weight gain in rabbits treated with aqueous extract of neem or deltamethrin. (Mean \pm SEM).

\begin{tabular}{|c|c|c|c|c|c|c|c|}
\hline & \multirow{3}{*}{$\begin{array}{l}\text { Initial body } \\
\text { weight }\end{array}$} & \multicolumn{2}{|c|}{ Days post-treatment } & & & & \\
\hline & & \multicolumn{2}{|c|}{14} & \multicolumn{2}{|c|}{28} & \multicolumn{2}{|c|}{42} \\
\hline & & Body weight & cBody gain & Body weight & cBody gain & Body weight & cBody gain \\
\hline $\begin{array}{l}\text {-ve } \\
\text { control }\end{array}$ & $761.5 \pm 25.2^{\mathrm{a}}$ & $1062.6 \pm 21.7^{\mathrm{a}}$ & $301.1 \pm 14.2^{\mathrm{a}}$ & $1350.4 \pm 26.4^{\mathrm{a}}$ & $588.9 \pm 10.4^{\mathrm{a}}$ & $1660.7 \pm 32.4^{\mathrm{a}}$ & $899.2 \pm 13.3^{\mathrm{a}}$ \\
\hline $\begin{array}{l}+\mathrm{ve} \\
\text { control }\end{array}$ & $755.7 \pm 17.3^{\mathrm{a}}$ & $965.0 \pm 15.2^{\mathrm{b}}$ & $209.3 \pm 13.5^{b}$ & $1160.3 \pm 23.8^{d}$ & $404.6 \pm 8.7^{\mathrm{d}}$ & $1375.4 \pm 43.3^{d}$ & $619.7 \pm 16.4^{c}$ \\
\hline DMT & $755.4 \pm 16.3^{a}$ & $970.4 \pm 24.5^{b}$ & $215.0 \pm 17.7^{b}$ & $1255.7 \pm 43.2^{\mathrm{c}}$ & $500.0 \pm 11.5^{\mathrm{c}}$ & $1570.3 \pm 26.5^{c}$ & $814.9 \pm 24.7^{b}$ \\
\hline AEN & $756.3 \pm 28.5^{\mathrm{a}}$ & $967.2 \pm 28.3^{b}$ & $210.9 \pm 14.3^{b}$ & $1262.5 \pm 31.4^{b}$ & $506.0 \pm 13.2^{b}$ & $1632.2 \pm 33.7^{b}$ & $875.9 \pm 17.9^{\mathrm{a}}$ \\
\hline
\end{tabular}

SEM: stander error of mean; cBody gain: Cumulative body gain; -ve control: negative control (not infested \& not treated); +ve control: positive control (Infested \& not treated); DMT: infested and treated with deltamethrin locally $(0.005 \%)$; AEN= infested and treated with aqueous extract of neem locally $(25 \%)$. ${ }^{\text {a-d }}$ Mean values within a column followed by different lowercase letters were significantly different $(\mathrm{P} \leq 0.05)$.

\section{DISCUSSION}

In vitro, the present study observed that, DMT $(0.005$ $\%$ ) caused 92.5 and $100 \%$ mortality 24 and $48 \mathrm{~h} \mathrm{PT}$, respectively. DMT completely reduced mite infestation 42 days PT of rabbits with $0.005 \%$ solution, topically. In spite of the applied dose for treating rabbits, such efficacy of DMT was in harmony with the reports of other researches. A similar prolonged acaricidal effect was recorded after using a higher dose of DMT (0.05\%) (Ramadan 2009). Dipping of whole chickens in DMT caused prolonged and complete reduction $(100 \%)$ in the number of ticks till the end of the third week PT (Ramadan 2009). As sunlight does not break pyrethroids down, they stick to surfaces for weeks, killing any bypassing insect, which explains the prolonged effect of DMT (Dubey et al., 2011). Concerning the side effects of DMT, it induced neurotoxicity in rats (Gilmore et al., 2006), and the use of DMT has deleterious effects on male (Ben Slima et al.,2012) and female (Lemos et al., 2012) fertility in rats. In addition, DMT showed malformation, decrease in body weight and incomplete ossification in fetuses of rats (Kandil, 2006). Ecologically, treatment of sarcoptic mange with various acaricides like diazinon, fenvalerate, deltamethrin, and avermectin (Campbell 1989; Merck 2005) has been attempted with different grades of success, insecticides pollute the environment around animals (Gassner et al., 1997) and their side effects (Ahmad et al., 2012) overweigh their benefits. Consequently, healthcare providers now face a serious lack of new commercial acaricides, and new alternatives are urgently needed.

Botanicals could be an environment-friendly solution (Khater, 2013; Seddiek et al., 2013). Our in vitro study signposted that $20 \%$ AEN generated 68.75 and $100.00 \%$ mortality of S. scabiei var. cuniculi larvae after 24 and $48 \mathrm{~h}$, respectively. AEN comprised good effect against sarcoptic mite larvae in vitro as the
LC50 values were 11.91, 7.65, and $6.52 \%$, respectively, after treatment for 24,48 , and $72 \mathrm{~h}$, respectively. The $\mathrm{LT}$ values were 160.00 and $33.97 \mathrm{~h}$ after treatment with 5 and $10 \%$ AEN, respectively. Similar efficacies of neem against S. scabiei var. cuniculi had been reported in vitro. The LC50 value of neem oil was $2.908 \mathrm{~mL} / \mathrm{L}$ at $24 \mathrm{~h} \mathrm{PT}$, and the LT50 values of 500,250 , and $125 \mathrm{~mL} / \mathrm{L}$ were 1,2 , and $5 \mathrm{~h}$, respectively (Du et al., 2007). Chloroform extract of neem oil induced $100 \%$ mortality after $4.5 \mathrm{~h}$ of exposure at a concentration of $200 \mathrm{mg} / \mathrm{mL}$ in vitro, with an LC50 value of $0.1 \mathrm{mg} / \mathrm{mL}$ at $24 \mathrm{~h} \mathrm{PT}$ and LT50 of $15.3 \mathrm{~h}$ at a concentration of $7.5 \mathrm{mg} / \mathrm{mL}$ (Du et al., 2009). The LT50 values for neem oil $(10 \%)$ microemulsion and aqueous emulsion were 81.74 and $95.55 \mathrm{~min}$, respectively (Xu et al., 2010). The LC50 value of the petroleum ether extract of neem $(1.3 \mu \mathrm{L} / \mathrm{mL})$ was about three times that of the chloroform extract $(4.1 \mu \mathrm{L} / \mathrm{mL})$ at $24 \mathrm{~h} \mathrm{PT}$. At a concentration of $500.0 \mu \mathrm{L} / \mathrm{mL}$, the LT50 values of the petroleum ether extract and the chloroform extract were 8.4 and $9.6 \mathrm{~h}$, respectively (Du et al., 2008). Petroleum ether extract of neem oil and its four fractions (F1-F4) possess useful acaricidal activity in vitro as the LC50 value was $70.9 \mathrm{~mL} / \mathrm{L} 24 \mathrm{~h}$ after treatment. At concentrations of 500.0, 250.0, 125.0, 62.5 , and $31.2 \mathrm{~mL} / \mathrm{L}$, the LT50 values of the petroleum ether extract were 8.7, 8.8, 10.8, 11.5, and $13.1 \mathrm{~h}$, respectively. Acaricidal activities of 68.3 and $100.0 \%$ in F2 and F4 were confirmed (Deng et al., 2012). In contrast to our results and the previous Endings, Walton et al. (2000) reported that neem showed little acaricidal activity against $\mathrm{S}$. scabiei var. hominis.

Our in vivo trial indicated that rabbits infested with S. scabiei var. cuniculi adult and not treated showed mange infestations on the nose, and legs with minor signs of recovery. On the contrary, rabbits treated with DMT and AEN exhibited improvement of clinical signs during the experiment. The reduction 
percentage of S. scabiei mites on rabbits was 100 and $99 \%$ after treatment with DMT and AEN for 42 days PT, respectively, which was represented clinically by the absence of macroscopic lesions. Likewise, neem oil had been reported to induce recovery of mange affecting other animals, such as sheep (Hirudkar et al., 1997; Tabassam et al., 2008) and dog (AbdelGhaffar et al., 2008a). Neem ointment (5\%) was effective against ear canker of rabbits, psoroptes cuniculi (Joshi et al., 2000). Moreover, neem induced an effective in vivo control of the poultry mite, Dermanyssus gallinae (Lundh et al., 2005; AbdelGhaffar et al., 2008b; Locher et al., 2010a, b).

Similar to DMT, our in vivo data indicated that neem extract completely cured mange in rabbits. Similarly, the undiluted neem oil killed all $S$. scabiei var. cuniculi larvae and was significantly higher than pyrethrins, but not significantly different from avermectin (Du et al., 2007). Crude aqueous methanol extract of neem seed kernel (20\%) was found as effective as ivermectin against sarcoptic mange infesting sheep under field conditions (Tabassam et al., 2008).

Regarding index scoring, the index scores of rabbits infested with S. scabiei var. cuniculi and treated with DMT or AEN were significantly decreased when compared with those of the infested and non-treated ones (positive control group). Equivalent improvement of lesion scoring was reported for neem as an acaricide against mange in dog (Abdel-Ghaffar et al., 2008a) and sheep (Tabassam et al., 2008).

The pesticidal activity of neem oil is generally thought to be due to the tetranortriterpenoid and azadirachtin (Isman et al., 1990). Azadirachtin induces feeding and oviposition deterrence, growth inhibition, and fertility \& fitness reductions (Schmutterer 1990). Azadirachtin is a natural plant defense chemical affecting feeding through chemoreception (primary anti-feedancy) that consists in the blockage of the input from receptors that normally respond to phagostimulants or from the stimulation of specific deterrent cells or both (Chapman 1974; Dethier 1982) and through a reduction in food intake due to toxic effects if consumed (secondary antifeedancy), where food intake is reduced after the application of azadirachtin in ways which bypass the mouth part chemoreceptors. In addition, Azadirachtin has growth regulatory effects on larval insects like disruption of molting, growth inhibition, and malformation, which may contribute to mortality. This is attributed to a disruption of endocrine events such as the down regulation of hemolymph ecdysteroid level through the blockage of release of the prothoracicotropic hormone from the brain-corpus cardiacum complex or to a delay in the appearance of the last ecdysteroid peak showing complete molt inhibition (Mordue and Blackwell 1993).
Biochemical analyses indicated that no significant difference of serum AST and total cholesterol in rabbits treated with DMT or AEN when compared with those values in negative control group (rabbits not infested and not treated). While, infested and not treated rabbits (positive control) showed a significant increase of serum AST and total cholesterol. Such results were in agreement with those mentioned for rabbits (Seddiek et al., 2013), layer chickens (Buim et al., 2013) and cattle (Hussein et al., 2008). However, these results were in disagreement with those obtained for goat (Kumar et al., 2010). Ogbuewu et al., (2010a) reported that neem leaf meal-based diets decreased the serum cholesterol level in rabbit bucks. Serum ALT \& creatinine showed no significant difference in all treated groups. Our study revealed that, AEN-treated group did not show any significant difference in serum total protein, albumin and globulin when compared with negative control group. These results were in disagreement with those obtained for rabbits (Seddiek et al., 2013). On the other hand, rabbits infested and not treated (positive control) showed a significant decreased in serum total protein, albumin, and globulin when compared with the corresponding values of other groups. This result similar to that obtained for rabbit (Seddiek et al., 2013) and cattle (Hussein et al., 2008).

In our study, AEN could be considered as safe because it had no side effect on the liver and kidney of the treated rabbits. Our data pointed out to the hepato- and renal- protective effects of the neem extract. Similar results were reported by Khalifa et al. (1998) as they found that water suspension of dried leaves of A. indica was hepatoprotective in rabbits infected with Eimeria stiedae, and also by Ezz- Din et al. (2011) who found that the use of A. indica leaf extract was a promising renal and hepatoprotective agent in rats due to its antioxidant effect and normalization of impaired kidney and liver Unction activities.

Regarding growth performance of rabbits in the present study, the body weight and cumulative body weight gain of rabbits in the infested and non-treated group were significantly decreased compared to values of the treated groups. The body weight and cumulative body weight gain of rabbits treated with AEN were significantly increased when compared with such values of positive control group and those treated with DMT $(0.005 \%)$, on 28 and 42 days PT. Similar results were reported (Bawa et al., 2007; Ogbuewu et al., 2010a, b and Seddiek et al., 2013). While this result was in disagreement with that obtained for rabbits fed leaf meal $(15 \%)$ for 16 weeks. the rabbits did not show any deleterious effects on body weight gain (Ogbuewu et al., 2010b).

AEN was found safe for rabbits, as indicated by biochemical analyses in the present study. There are 
no skin irritations or restlessness during the time of application and afterwards. Similar results had been reported (Tabassam et al., 2008; Schmahl et al., 2010). Along with the economic benefits, additional advantages of using neem pesticides are that they have low environmental persistence (Sundaram and Curry 1994), do not induce resistance readily in insects (Feng and Isman 1995; Jacobson 1995), and are relatively nontoxic to mammals (Jacobson 1995; Larson 1989) and non-target organisms (Condor_Golec 2007).

It could be concluded that AEN had in vitro and in vivo acaricidal efficiency similar to that of DMT. It improved the growth performance (body weight and gain) of rabbits infested with S. scabiei var. cuniculi. No significant signs of side effects or adverse reactions were noticed throughout the study. These data provide a platform for the development of environment-friendly, non-toxic, non-accumulating medicines against acariasis, which could be carried out in a large scale in rabbit farms. Consequently, AEN could be suitable as a promising alternative acaricide for veterinary use. Botanicals could create an herbal remedy export market and thereby create more jobs in developing countries, which will improve our national economy.

\section{ACKNOWLEDGMENT}

The authors thank Prof. Dr. Hanem F. Khater, professor of parasitology, faculty of Vet. Medicine, Benha Univ. Egypt, for her support and advice.

\section{REFERENCES}

Abdel-Ghaffar, F.; Al-Quraishy S.; Sobhy, HM. and Semmler, M. (2008a): Neem seed extract shampoo, Wash away Louse®, an effective plant agent against Sarcoptes scabiei mites infesting dogs in Egypt. Parasitol. Res. 104: 145-148.

Abdel-Ghaffar, F.; Sobhy, HM.; Al-Quraishy, S. and Semmler, M. (2008b): Field study on ef£cacy of an extract of neem seed (Mite-Stop) against the red mite Dermanyssus gallinae naturally infecting poultry in Egypt. Parasitol Res 103(3): 481-48.

Abdel-Shafy, S. and Zayed, AA. (2002): In vitro acaricidal effect of plant extract of neem seed oil (Azadirachta indica) on egg, immature, immature, and adult stages of Hyalomma anatolicum excavatum (Ixodoidea, Ixodidae). Vet Parasitol. 16: 89-96.

Aiello, SE.; Mays A. and Amstutz, HE. (1998): Rabbits. In: Aiello SE (ed) Merck veterinary manual. Merck Inc., Whitehouse Station, NJ, pp 1386-1396.

Bawa, GS.; Orunmuyi, M.; Agbaji, AS.; Ladan, Z. and Okekeifi, UO. (2007): Effect of different methods of processing neem (Azadirachta indica) seeds on performance of young rabbits. Pakistan j Nutr 6(3): 212-216.

Ben Slima, A.; Ben Abdallah, F.; Keskes-Ammar, L.; Mallek, Z.; El Feki, A. and Gdoura, R. (2012): "Embryonic Exposure to Dimethoate and/or Deltamethrin Impairs Sexual Development and Programs Reproductive Success in Adult Male Offspring Mice." Andrologia 44 Suppl 1: 661-666.

Biswas, KI.; Chattopadhyay, A.; Banerijee, YA. and Bandopadhyay, U. (2002): Biological activities and medicinal properties of neem (Azadirachta indica). Curr Sci 82: 1336-1345.

BioStat (2009): 5.8.3.0. Statistical software. downloaded from: http://biostat-2009. soft 112.com

Buim Marcos Roberto; Andreia Mauruto Chernaki Leffer; Claudia Del Fava; Helenice de Souza Spinosa; Rachel Santos Bueno and Silvana Lima Górniak (2013): The First Report about Allopsoroptoides galli n. g., n. sp (Acari: Analgoidea: Psoroptoididae) Infected Layer Hens: Hematological, Serum Chemistry, and Histopathologic Findings. International Journal of Poultry Science 12 (5): 261-263.

Campbell, WW. (1989): Ivermectin and abamectin. Springer, New York.

Chapman, RF. (1974): Chemical inhibition of feeding by phytophagus insects-a review. Bull Ent Res 64: 339-363.

Cóndor_Golec, AF. (2007): Effect of neem (Azadirachta indica A. Juss) insecticides on parasitoids. Rev. Peru. Biol. 14(1): 69-74.

Currie, BJ.; Harumal, P.; McKinnon, M. and Walton, $F$. (2004): First documentation of in vivo and in vitro ivermectin resistance in Sarcoptes scabiei. Clin Infect Dis 39(1): e8-e12.

Deng, Y.; Shi, D.; Yin, Z.; Guo, J.; Jia, R.; Xu, J.; Song, X.; Lv, C.; Fan, Q.; Liang, X.; Shi, F.; $Y e$, G. and Zhang, W. (2012): Acaricidal activity of petroleum ether extract of neem (Azadirachta indica) oil and its four frac $\neg$ tions separated by column chromatography against Sarcoptes scabiei var. cuniculi larvae in vitro. Exp Parasitol 130(4): 475-477.

Dethier, VG. (1982): Mechanisms of host plant recognition. Entomologia Exp Appl 31: 49-56.

Domas, B.L. (1975): Colorimetric determination of total protein. Clin. Chem., 21(1): 159-166.

Dogmas, B. (1971): Colorimetric method for albumin determination.

Du, YH.; Jia, RY.; Yin, ZQ,; Pu, ZH.; Chen, J.; Yang, F.; Zhang, YQ. and Lu, Y. (2008): Acaricidal activity of extracts of neem (Azadirachta indica) oil against the larvae of the rabbit mite Sarcoptes scabiei var. cuniculi in vitro. Vet Parasitol 157(1-2): 144-148.

Du, YH.; Li, JL.; Jia, RY.; Yin, ZQ.; Li, XT.; Lv, C.; Ye, G.; Zhang, L. and Zhang, YQ. (2009): Acaricidal activity of four fractions and 
octadecanoic acid-tetrahydrofuran-3,4-diyl ester isolated from chloroform extracts of neem (Azadirachta indica) oil against Sarcoptes scabiei var. cuniculi in vitro. Vet Parasitol 163(1-2): 175-178.

Du, YH.; Yin, ZQ.; Pu, ZH.; Li, W.; Li, JD. and Yu, SS. (2007): Acaricidal activity of neem oil against Sarcoptes scabiei var. cuniculi in vitro. Vet Sci China 63(2): 75-78.

Dubey, NK.; Shukla, R.; Kumar, A.; Singh, P. and Prakash, B. (2011): Global scenario on the application of natural products in integrated pest management programs. In: Dubey NK (ed) Natural products in plant pest management. CAB International, London, pp $1-20$.

Duncan, DB. (1955): Multiple range and multiple F tests. Biometrics 11: 142.

El-Mahmood, AM.; Ogbonna, OB. and Raj, M. (2010): The antibacterial activity of Azadarichta indica (neem) seeds extracts against bacterial pathogens associated with eye and ear infections. J. Med. Plants Res 4(14): 1414-1421.

Ezz-Din, D.; Gabry, SM.; Farrag, AH. and Abdel Moneim, AE. (2011): Physiological and histological impact of A. indica (neem) leaves extract in a rat model of cisplatin-induced hepato and nephrotoxicity. J. Med. Plants Res 5(23): 5499-5506.

Feng, R. and Isman, MB. (1995): Selection for resistance to azadirachtin in the green peach aphid, Myzuspersicae. Experientia 51: 831-833.

Finney, DJ. (1971): Probit analysis. Cambridge University Press, Cam-bridge, pp 303.

Flegg, HM. (1973): Quantitative-enzymaticcolourimetric determination of total cholesterol and HDL-C in serum or plasma. Ann Clin Biochem 10: 79-88.

Gassner, B.; Wtilhrich, A.; Lis, J.; Scholtysik, G. and Solioz, M. (1997): Topical application of synthetic pyrethroids to cattle as a source of persistent environmental contamination. J. Environ Sci. Health B 32: 729-739.

Gilmore, RG.; Sheets, LP. and Hoss, HE. (2006): A developmental neurotoxicity screening study with technical grade deltamethrin in Wistar rats. Stilwell, Kansas 66085-9104, Bayer CropScience LP Toxicology.

Halley, BA.; Vandenheuvel, WJA.; Wislock, PG.; Herd, R.; Strong, L. and Wardhaugh, K. (1993): Environmental effects of the usage of avermectines in livestock. Vet Parasitol 48: 109-125.

Henry, RJ. (1974): Clinical chemistry, principles and techniques, 2nd edn. Harper and Row, Hagerstown, MD.

Hirudkar, US.; Deshpande, PD.; Narladkar, BW. and Vadlamudi, VP. (1997): Effect of herbal treatment with himax ointment and neem oil in sarcoptic mange in sheep. Indian Vet. J. 74: 506-508.

Harrenstien, L.; Gentz, EJ. and Carpenter, JW. (1995): How to handle respiratory, ophthalmic, neurological and dermatologic problems in rabbits. Proceedings of the Symposium on Rabbit Medicine, 4 April, Lenexa, Kansas. Vet Med. 90(4): 373-380.

Haussain, HEMA. (2002): Reversal of diabetic retinopathy in streptozotocin induced diabetic rats using traditional Indian antidiabetic plant, Azadirachta indica L. Indian J. Clinic Biochem 17(2): 115-123.

Hussein, H.A.; Abd-EL-Salam, M.N. and Karram, M.H. (2008): Mite and tick infestation in cattle: haemogram and some biochemcal parameters. SCVMJ, XIII (1) pp. 161-170.

Isman, MB.; Koul, O.; Luczynski, A. and Kaminski, J. (1990): Insecticidal and antifeedant bioactivities of neem oils and their relationship to azadirachtin content. J. Agric Food Chem 38: 1406-1411.

Jacobson, M. (1995): Toxicity of neem to vertebrates and side effects on beneficial and other ecologically important non-target organisms: toxicity to vertebrates. In: Schmutterer H (ed) The neem tree: source of unique products for integrated pest management, medicine, industry, and other purposes. VCH Weinheim, Germany, pp 484-495.

Jensen, JCE.; Nielsen, LH.; Arnason, T. and Cracknell, V. (2002): Elimination of mange mites Sarcoptes scabiei var. suis from two naturally infested Danish sow herds using a single injection regime with doramectin. Acta Vet Scand 43: 75-84.

Joshi, SS.; Dakshinkar, NP.; Sapre, VA. and Sarode, DB. (2000): Evaluation of herbal medicaments in psoroptic mange of rabbits. Indian Vet. 77: 706-708.

Khalifa, SAM. Al-Elyani, RAA. and Toulah, FHS. (1998): The effect of dried leaves water suspension of neem plant (Azadirachta indica) on some organs of rabbits (Oryctolagus cuniculus L.) infected by coccidiosis (E. stiedae K.). 1. Some cytological and histological studies on the liver. Egypt $\mathrm{j}$ Histol 21(1): 19-32.

Kandil, AM. (2006): "Toxic Effects of Deltamethrin on the Pregnant Rats and Their Fetuses." J. Drug Res. 27: 82-89.

Khater, HF. (2011): Ecosmart biorational insecticides: alternative insectcontrol strategies. In: Perveen F (ed) Advances in integrated pest management. InTech, Croatia, pp 17-60.

Khater, HF. (2012): Prospects of botanical biopesticides in insect pest management. Pharmacologia 3(12): 641-656. 
Khater, HF. (2013): Bioactivity of essential oils as green biopesticides: recent global scenario. In: Govil JN, Bhattacharya S (eds), Recent progress in medicinal plants, vol. 37. Essentials oils II. Studium Press LLC, USA (in press).

Khater, HF. and Shalaby, AA. (2008): Potential of biologically active plant oils for control mosquito larvae Culex pipiens (Diptera: Culicidae) from an Egyptian locality. Rev Inst Med Trop S Paulo 50(2): 107-112.

Khater, HF. and Ramadan, MY. (2007): The acaricidal effects of peracetic acid against Boophilm annulatus and Argas persicus. Acta Sci Vet 35: 29-40.

Khater, HF.; Ramadan, MY. and Abdel Mageid, AD. (2013b): In vitro control ofthe camel nasal botfly, Cephalopina titillator, with doramectin, lavender, camphor, and onion oils. Parasitol Res. (in press).

Khater, HF.; Ramadan, MY. and El-Madawy, RS. (2009): Lousicidal, ovicidal, and repellent efficacy of some essential oils against lice and flies infesting water buffaloes in Egypt. Vet Parasitol 164: 257-266.

Khater, HF.; Seddiek, SA.; El-Shorbagy, MM. and Ali, MM. (2013a): The acaricidal efficacy of peracetic acid and deltamethrin against the fowl tick, Argas persicus, infesting laying hens. Parasitol Res. 112(1): 259-269.

Kumar, Arvind; Vihan, V.S.; Sadhana and Sharma, H.N. (2010): Haematological and biochemical effects of tick infestation in common Indian goat. Advances in Bioresearch, Vol. 1(11): 163-168.

Larson, RO. (1989): The commercialization of neem In: Jacobson M (ed) 1988 Focus on phytochemical pesticides, vol. 1. The neem tree. CRC, Boca Raton, pp 155-168.

Lemos, AJ.; Siqueira, HA.; Wanderley-Teixeira, V.; Maia, FC.; Teixeira, AA; Silva, EJ. and Oliveira, JV. (2012): "Effect of Sub-Lethal Doses of Bacillus Thuringiensis Subsp. Aizawai and Deltamethrin with Regard to Fertility and Organ Toxicity in Pregnant Albino Rats." Experimental and Toxicologic Pathology. 5(2): 142-154.

Locher, N.; Al-Rasheid, KA.; Abdel-Ghaffar, F. and Melhorn, H. (2010a): In vitro and field studies on the contact and fumigant toxicity of a neem- product (Mite-Stop) against the developmental stages of the poulhy red mites Dermanyssus gallinae. Parasitol Res 107(2): 417-443.

Locher, N.; Klimpel, S.; Abdel-Ghaffar, F.; AlRasheid, KA. and Melhorn, H. (2010b): Light and scanning election microscopic investigations on MiteStop-treated poultry red mites. Parasitol Res 107(2): 433-437.
Lundh, J.; Wiktelius, D. and Chirico, J. (2005): Azadirachtin-impregnated traps for the control of Dermanyssus gallinae. Vet Parasitol 130(34): 337-342.

Mehlhorn, H.; Schumcher, B.; Jatzlau, A.; AbdelGhaffar, F.; Al-Rasheid, KAS.; Klimpel, S. and Pohle, H. (2011): Efficacy of DMT (Butox ${ }^{\circledR}$ 7.5 pour on) against nymphs and adults of ticks (Ixodes ricinus, Rhipicephalus sanguineus) in treated hair of cattle and sheep. Parasitol Res 108(4): 963-971.

Merck, $R$. (2005): The Merck veterinary manual, 9th edn. Merck and Co., Whitehouse Station, NJ.

Mohamed, AEH. El-Sayed, MA.; Hegazy, ME.; Helaly, SE.; Esmail, AM. and Mohamed, NS. (2010): Chemical constituents and biological activities of Artemisia herba-alba. Rec Nat Prod 4: 1-25.

Mordue, AJ. and Blackwell, A. (1993): Azadirachtin: an update. J Insect Physiol 39: 903-924.

Mulla, MS. and Su, T. (1999): Activity and biological effects of neem products against arthropods of medical and veterinary importance. j Am Mosq Consol Assoc. 15: 133-152.

Nong, X.; Ren, Y.; Wang, j.; Fang, C.; Xie, Y.; Yang, D.; Liu, T.; Chen, L.; Zhou, Z.; Gu, X.; Zheng, W.; Peng, X.; Wang, S.; Lai, S. and Yang, G. (2013): Clinical efficacy of botanical extracts from Eupatorium adenophorum against scab mite, Psoroptes cuniculi. Vet Parasitol. 192 (1-3): 247-252.

O'Brien, Dj. (1999): Treatment of psoroptic mange with reference to epidemiology and history. Vet Parasitol 83(3-4): 177-185.

Ogbuewu, IP.; Uchegbu, MC.; Okoli, IC. and Iloeje, MU. (2010a): Toxicological effects of leaf meal ethnomedicinal plant-neem-on serum biochemist of crossbred New Zealand white typed rabbit bucks. Rep Opin 2(2): 54-57.

Ogbuewu, IP.; Uchegbu, MC.; Okoli, IC. and Iloeje, $M U$. (2010b): Assessment of blood chemistry, weight gain and linear body measurements of pre-pubertal buck rabbits fed different levels of neem (Azadirachta indica A. juss) leaf meals. Chilean j Agric Res 70(3): 515-520.

Ramadan, MY. (2009): Acaricidal and immunological Studies opn fowl tick Argas persicus Infecting Commercial Balady Chickens Flock. Third Inter. Sci. Conf., 29 Jan.- 1 Feb./ 2009, Benha and Ras Sudr, Egypt Faculty of Veterinary Medicine, Benha University.

Saha, SB. and Mukherjee, S. (1998): Sarcoptic mange in domestic rabbits. Indian J. Anim. Health 37: 73 .

Schmahl, G.; Al-Rasheid, KA.; Abdel-Ghaffar, F.; Klimpel, S. and Melhorn, H. (2010): The efficacy of neem seed extracts (Tre-San, MiteStop on a broad spectrum of pets and parasites). Parasitol Res 107(2): 261-269. 
Schmutterer, H. (1990): Properties and potential of natural pesticides from the neem tree, Azadirachta indica. Annu. Rev. Entomol 35: 271-297.

Seddiek, SA.; Ali, MM.; Khater, HF. and ElShorbagy, MM. (2011): Anthelmintic activity of the white wormwood, Artemisia herba-alba against Heterakis gallinarum infecting turkey poults. J. Med. Plant Res 5(16): 3946-3957.

Seddiek, Shaker A.; Hanem F. Khater; Mohamed M. El-Shorbagy and Ali M. Ali (2013): The acaricidal efficacy of aqueous neem extract and ivermectin against Sarcoptes scabiei var. cuniculi in experimentally infested rabbits. Parasitol Res (2013) 112: 2319-2330.

Shalaby, AA. and Khater, HF. (2005): Toxicity of certain solvent extracts of Rosmarinus officinalis against Culex pipiens larvae. j Egypt- German Soc Zool 48E: 69-80.

Soulsby, EJL. (1982): Helminths, Arthropods and Protozoa of domesticated animals, 7 th edn. Baillière Tindall, London.

SPSS Inc. Released (2009): PASW Statistics for Windows, Version 18.0. Chicago: SPSS Inc.

Sundaram, KMS. and Curry, J. (1994): Initial deposits and persistence of azadirachtin in fir and oak foliage after spray application of
Margosan-O® formulation. Pestic Sci 41: 129-138.

Tabassam, SM.; Iqbal, Z.; Jabbar, A.; Sindhu, ZU. and Chattha, AI. (2008): Efficacy of crude seed neem kernel extracts against natural infestation of Sarcoptes scabiei var. ovis. J. Ethnopharmacol 115(2): 284-287.

Varliy, H. (1974): Clinical chemistry methodology, past and present. Ann. Clin. Chem., 11: 161-63.

Walton, SF. and Currie, BJ. (2007): Problems in diagnosing scabies, a global disease in human and animal populations. Clin Microbiol Rev 20(2): 268-279.

Walton, SF.; Myerscough, MR. and Currie, BJ. (2000): Studies in vitro on the relative efficacy of current acaricides for Sarcoptes scabiei var. hominis. Trans R Soc Trop Med Hyg 94: 92-96.

Xu, J.; Fan, QJ.; Yin, ZO.; Li, XT.; Du, YH.; Jia, RY.; Wang, KY.; Lv, C.; Ye, G.; Geng, Y.; Su, G.; Zhao, L.; Hu, TX.; Shi, F.; Zhang, L.; Wu, CL.; Tao, C.; Zhang, XY. and Shi, DX. (2010): The preparation of neen oil microemulsion (Azadirachta indica) and comparison of acaricidal time between neem oil microemulsion and other formulations in vitro. Vet. Parasitol 11(3-4): 399-403.

\section{فعالية المستخلص المائي لنبات النييم و الالتاميثرين ضد حُلم الجرب (ساركوبتس سكابياى فاركونيكولاي) في الأرانب المعدية معملياً}

\section{على محد محد أحمد ، شاكر صديق عبد الرحمن ، مي عثمان محد عبد الفتاح ، سامح عبد المنعم محد الألفي}

Email: alimohamed312@yahoo.com Assiut University web-site: www.aun.edu.eg

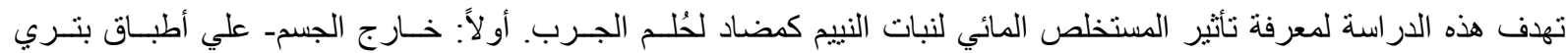
(in-vitro)

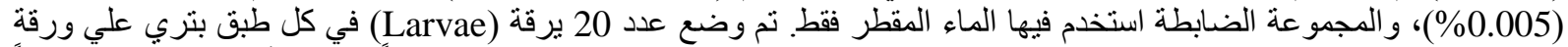

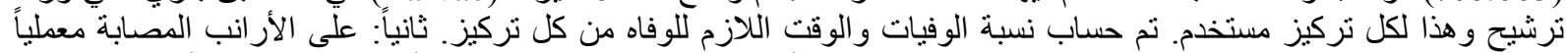

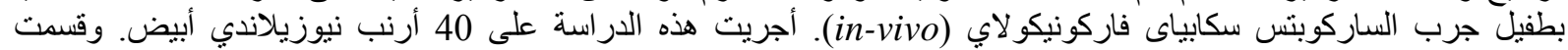

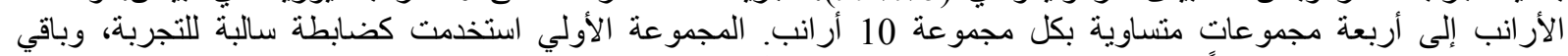

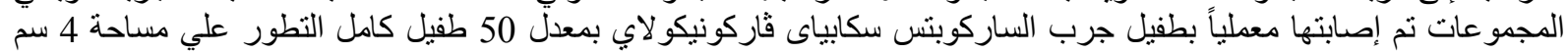

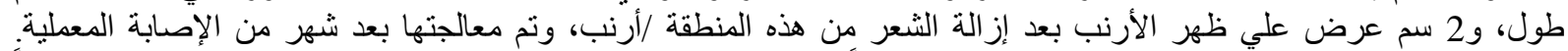

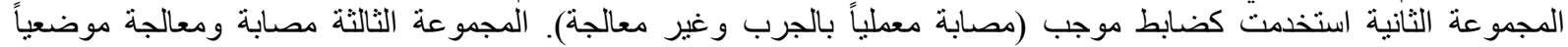

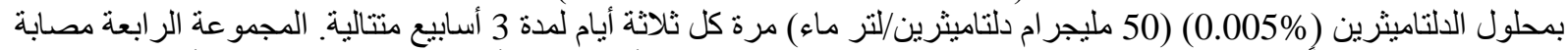

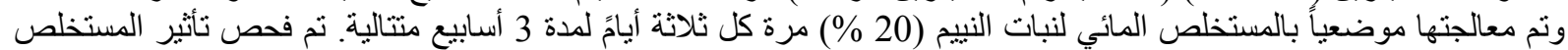

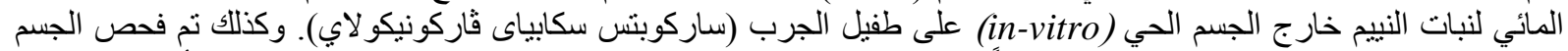

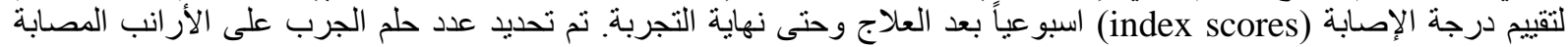

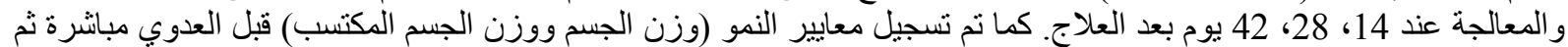

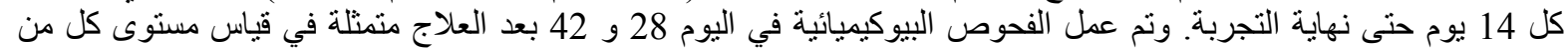

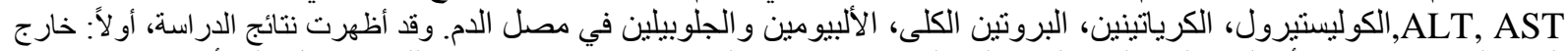

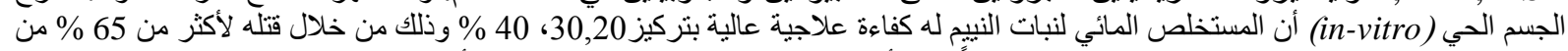

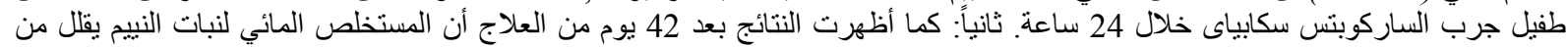

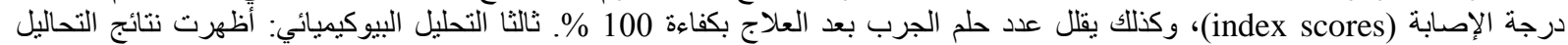

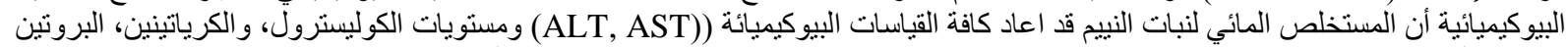

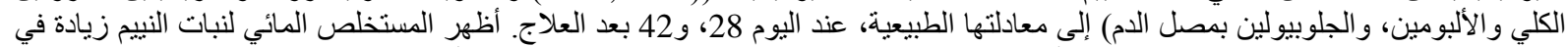

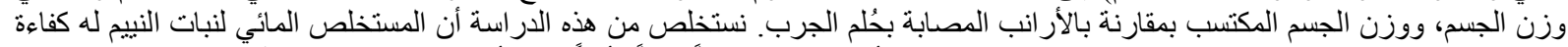

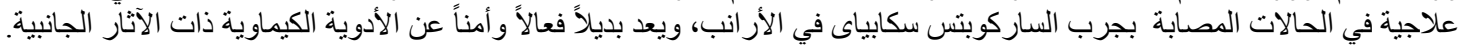

